\title{
Giant cell tumour of dorsal vertebra: a case report
}

\begin{abstract}
Giant cell tumours of the spine are rare entities. They are mainly seen in long bones. We report a patient with a giant cell tumour of D12 vertebrae which had undergone total en-bloc spondylectomy D11, D12, L1 vertebra and tumor. On histopathological examination, Hematoxylin and Eosin stained slides revealed giant cell tumour without any malignant changes.
\end{abstract}

Keywords: dorsal spine, giant cell tumour, vertebra, fine needle aspiration cytology, antitubercular treatment
Volume 2 Issue 3 - 2016

\author{
Rachana Dhakal,' Ramesh Makaju,' Dipak \\ Shrestha ${ }^{2}$ \\ 'Department of Pathology, Kathmandu University School of \\ Medical Sciences, Nepal \\ ${ }^{2}$ Department of Orthopedics, Kathmandu University School of \\ Medical Sciences, Nepal
} Correspondence: Rachana Dhakal, Department of Pathology,
Kathmandu University School of Medical Sciences, Nepal,Tel 977984I777944, Email sigdelrachana@gmail.com

\section{Introduction}

Giant cell tumour of bone accounts for $5 \%$ of primary bone tumours. ${ }^{1}$ It rarely arises in the spine. The incidence of giant cell tumour of mobile segment of spine accounts for $1-1.5 \%$ with an equal incidence in all three mobile segments of spine. ${ }^{2}$ They tend to be found in individuals in third and fourth decade of life. Women are affected slightly more than men. They are aggressive with high degree of malignant potential and are also associated with high incidence of local recurrences. ${ }^{3,4}$

\section{Case report}

A 35 year old female, presented with complaints of back pain since one year, difficulty while walking, and weakness and loss of sensation of bilateral lower limb since six weeks. She was investigated and started on Antitubercular treatment (ATT) for the same problem in the other hospital on the basis of MRI report which suggested Pott's disease. Symptoms persisted even after completion of six months course of ATT. After two months, ATT was started again from local center without improvement in the symptoms. So, the patient presented to the hospital for the aggravation of symptoms. On examination, she had tenderness over lower dorsal region with muscle power of grade 2 in the right lower limb and grade 1 in the left lower limb. There was bilateral decreased sensation from T12 dermatome and below and complete loss of sensation from L4 dermatome and below. Previous diagnosis was challenged and Fine needle aspiration cytology (FNAC) of the lesion was done. FNAC of the lesion revealed singly scattered round to ovoid cells with numerous osteoclastic giant cells suggestive of Giant cell lesion (Figure1). On the basis of FNAC report, CT scan of dorsal spine was suggested which showed collapsed D12 vertebral body with the lytic lesion at vertebral body and bilateral pedicles. Patient had undergone total en-bloc spondylectomy D11, D12, L1 vertebra and tumor. Then, the specimen was sent for histopathological examination. On gross examination, multiple pieces of bony fragments along with soft tissue were received. On microscopy, prominent and diffuse osteoclastic giant cell component without any malignant changes were seen (Figure2).

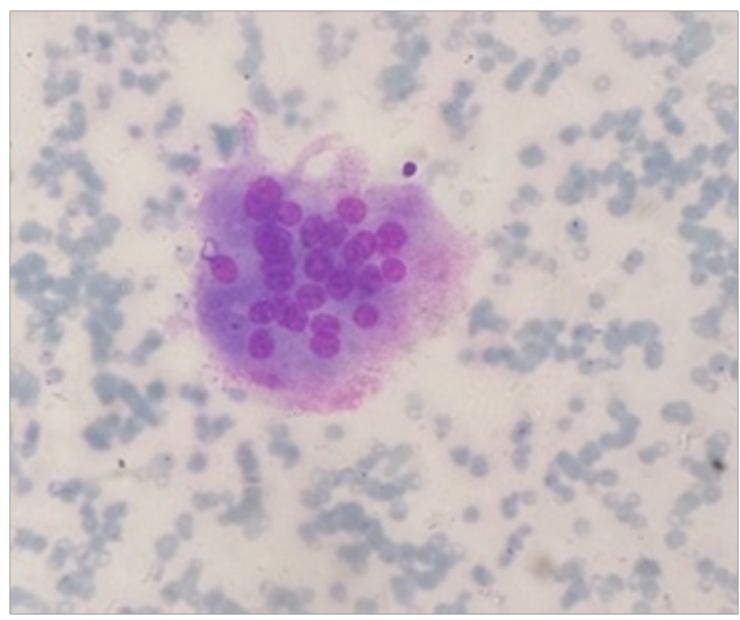

Figure1 Osteoclastic giant cells against hemorrhagic background (X40).

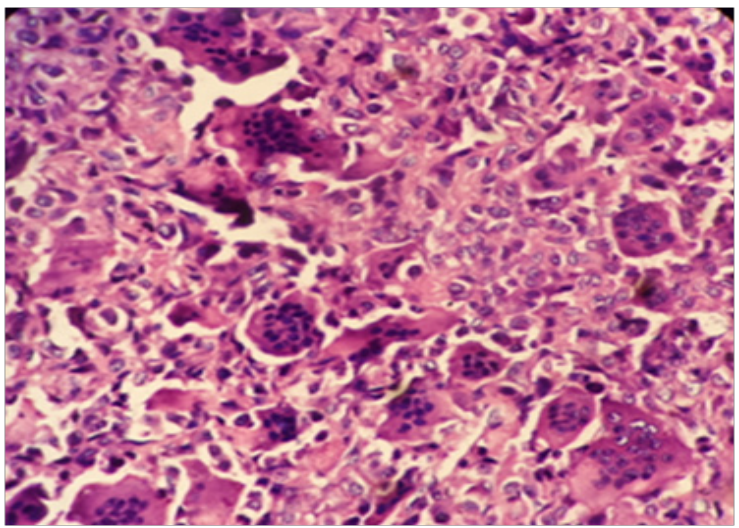

Figure 2 Giant cell tumour composed of round to ovoid cells in stroma with numerous multinucleated giant cells (X40). 


\section{Discussion}

Giant cell tumours are rarely multicentric. ${ }^{5}$ In the series of Savini, giant cell tumours of thoracic vertebra are very rare, being approximately $0.9 \% .{ }^{6}$ Common symptoms include back pain, neurological deficit due to compression of spinal cord, bladder and bowel dysfunction and a structural deformity of the spine. ${ }^{7}$ Gross pathologic appearance of the tumour is soft, friable and fleshy with presence of areas of fibrosis, hemorrhage and xanthomatous region. On microscopy, giant cell tumour contain a prominent and diffuse osteoclastic giant cell component and previously referred as osteoclastomas. Approximately, $10 \%$ of all giant cell tumours are malignant and they may metastasise to other organs. ${ }^{8-10}$ Metastatic involvement in the large series of benign giant cell tumours generally ranged from $1-6 \% .{ }^{10}$ Metastatic lesions occur mainly in the lungs. ${ }^{11-14}$ Solitary metastases to regional lymph nodes, the mediastinum and pelvis have also been reported. ${ }^{11}$ There are various modalities of treatment recommended for spinal giant cell tumours such as surgery, radiotherapy, embolization, cryotherapy, cementation and chemical adjuvant like phenol or liquid nitrogen. ${ }^{7}$ Total en bloc surgical excision is the treatment of choice in long bones as well as spine but is not always feasible in the spine due to the unacceptable risk of permanent neurological deficit. ${ }^{15}$

\section{Conclusion}

Giant cell tumour of thoracic vertebra is very rare. The best treatment is total excision. However, patients should be followed up carefully for lung metastasis and high recurrences.

\section{Acknowledgements}

None.

\section{Conflict of interest}

The author declares no conflict of interest.

\section{References}

1. Mendenhall WM, Zlotecki RA, Scarborough MT, et al. Giant cell tumour of bone. Am J Clin Oncol. 2006;29(1):96-99.

2. Campanacci M, Baldini N, Boriani S, et al. Giant cell tumour of bone. $J$ Bone Joint Surg Am. 1987;69(1):106-114.
3. Filder MW. Surgical treatment of giant cell tumours of the thoracic and lumbar spine: report of nine patients. Eur Spine J. 2001;10(1):69-77.

4. Durr HR, Maier M, Jansson V, et al. Phenol as an adjuvant for local control in the treatment of giant cell tumours of the bone. Eur J Surg Oncol. 1999;25(6):610-618.

5. Potter HG, Schneider R, Ghelman B, et al. Multiple giant cell tumours and Paget disease of bone: radiographic and clinical correlations radiology. Radiology. 1991;180(1):261-264.

6. Savini R, Gherlinzoni, Morandi M, et al. Surgical treatment of giant cell tumour of the spine.The experience at the Istituto Ortopedico Rizzoli. $J$ Bone Joint Surg Am. 1983;65(9):1283-1289.

7. Redhu R, Poonia R. Giant cell tumor of dorsal vertebral body. $J$ Craniovertebr Junction Spine. 2012;3(2):67-69.

8. Murphy WR, Ackerman LV. Benign and malignant giant cell tumours of bone; a clinical-pathological evaluation of thirty - one case. Cancer. 1956;9(2):317-339.

9. Dahlin DC. Caldwell Lecture. Giant cell tumour of bone: highlights of 407 cases. AJR Am J Roentgenol. 1985;144(5):955-960.

10. Goldenberg RR, Campbell CJ, Bonfiglio M. Giant cell tumour of bone. An analysis of two hundred and eighteen cases. J Bone Joint Surg. 1970;52(4):619-664.

11. Rock MG, Pritchard DJ, Unni KK. Metastases from histologically benign giant cell tumour of bone. J Bone Joint Surg. 1984;66(2):269-274.

12. Bertoni F, Present D, Sudanese A, et al. Giant cell tumour of bone with pulmonary metastases. Clin Orthop Relat Res. 1988;237:275-285.

13. Gresen AA, Dahlin DC, Peterson LF, et al. Benign giant cell tumour of bone metastasizing to lung. Ann Thorac Surg. 9173;16(5):531-35.

14. Stargardtes FL, Cooperman LR. Giant cell tumour of sacrum with multiple pulmonary metastases and long term survival. $\mathrm{Br} J$ Radiol. 1971;44(528):976-979.

15. Boriani S, Weinstein JN, Biagini R. Primary bone tumors of the spine. Terminology and surgical staging. Spine (Phila Pa 1976). 1997;22(9):106144 . 